University of Louisville

ThinkIR: The University of Louisville's Institutional Repository

Electronic Theses and Dissertations

1931

\title{
A study in local anesthesia diethanolaminoethylester of para- aminobenzoic acid.
}

Wilbur P. Crouch 1907-1964

University of Louisville

Follow this and additional works at: https://ir.library.louisville.edu/etd

Part of the Anesthesiology Commons, Chemicals and Drugs Commons, and the Surgery Commons

\section{Recommended Citation}

Crouch, Wilbur P. 1907-1964, "A study in local anesthesia diethanolaminoethylester of para-aminobenzoic acid." (1931). Electronic Theses and Dissertations. Paper 1692.

https://doi.org/10.18297/etd/1692

This Master's Thesis is brought to you for free and open access by ThinkIR: The University of Louisville's Institutional Repository. It has been accepted for inclusion in Electronic Theses and Dissertations by an authorized administrator of ThinkIR: The University of Louisville's Institutional Repository. This title appears here courtesy of the author, who has retained all other copyrights. For more information, please contact thinkir@louisville.edu. 


\title{
UAIVERSI TI OF LOUISVILLE
}

\author{
A STUDY IN LOCAL ANESTHESIA
}

DIETHAMOTAMIMOE THED.ES TER OF PARA-AMIMOBENZOIC ACID

\author{
A DLesertution \\ subal tted to the Fecults \\ or the Greduate Sohool of the Uniteralty of Loulavilie \\ In Partial Fureiliment of the \\ Requirenents for the Degree \\ or Master of Solonoe
}

Dopartment of Chenistry

By

NLIbur F. Crouch

(2032) 


\section{TARE OR CON TEX TS}

I. Introduction $-\cdots+-\infty-\infty \cdots+-\infty$

II. Expexinental

III. Conoludions

IV. Blbllogtaghy - - - -

7. Autoblogxaphy $-\cdots$ 


$$
-
$$


we story of enesthotios is as old as the world 1teelf. As woon as man hed doreloped to tho exteat that he was able to thinly ho has atteapted

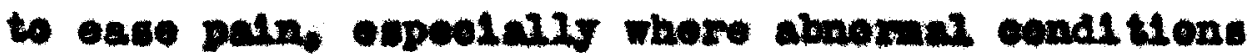
of the body had to be rolloved. sone of the ear11est attempte at general anesthesta wore with exve-

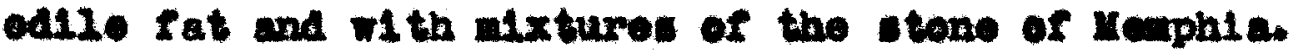
some of the carler attempto at lood anestherle were by outting of wome of the maln arterten. and by application of presenre upon some of the maln artories or nertes of the 14mbs, thoreby dausing that part to fall allopp. This nothod is coseribed in the frieses on the tombe of the Egypthans as oarly 252500 B.C. $(L)$. Freesling of a portion of the body Wth a alxture of salt and 100 in the oariy ages and later ther and thrl obloride have beon used. Ethy ohloride 1: still used in thl fachlon. For nony conturies the netive of Peru and Bollris rnen that the leares of the eooa plant wore are ageat for leseoning patn. One of the crude eardy mothad was the obowins of the leates and allowing the sal1ra to Amp inte the wound. In 1860 Nolman 1eolated Imo-ocouine from the leaves of tho orythroxyzon ooca by Eminding the zeares into a powder and oxtrootins with alleurio aold. Thl compound was found to possens loon anesthotte properties, and In 1884 Dr. Keller denenstrated at VIenna the 
Inportance of cocalne in aurgery. It was found by experimentation that the bout selution to use was a 2 f eelution of the hydroeklome selt. At firat cocalne was uged prinelpaly in the ores, but it was lator found to be a very good local anesthetio for external wort, oupecially for tumore, and oor, nose and threat surgery (2). After the 160lation of cocalne, a great aeal of work was done in the doternination of the atruoture of the cooalne melecule. Losmen(3)

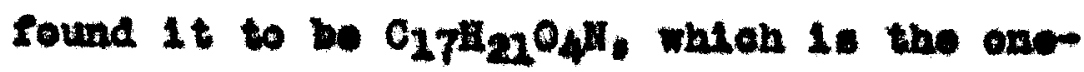

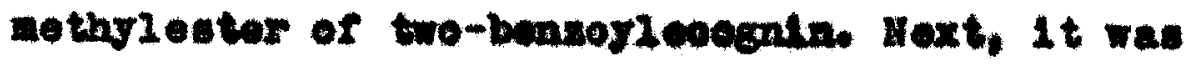
necessury to find eut what part of the molecule gorerned the power of anesthoula, whether $1 t$ was one Eroug or several groups acting in unison to produce thi action, or whether the position of the Group, or Eroups, in the moleatle had anvthing to do with the anesthetio action and the texiolty. It wes alsoorowed that in pract1oarly all ouses, the conpound that showed aneethette action had at least one anine group and one bydroxyl group, al though there were found exooptions to this, for exemple, bensyl alcohol. It was round also that in orter for a ooupound to wow aneathetle wotien the hrdroxyl group must be entertitias. 
The propertios of a seed anepthotio are a follow, aceording to pournoun(4):

1. Eanily coluble in rator.

2. Should be oapable of unaorgolng temilsation by hot in water colutlon.

3. Almest tastelecs.

4. Possest no pronounced toxto proportlos.

5. Cause wo marting wanestion when introduced undor the ofe-1Lds or injected under the ardn. 6. Hare a ctrong anosthotic action, Interse and continuous, bat not vilent. 7. Hare no permenent afroot on the nerve flbert, and hould pass aray coupletely.

8. Should ghow rasooonitrietire activity and runder the thieues and curfoces with whioh $1 t$ comes In contast bloodless.

9. Not too costly.

10. Not form prealp1 tate w1 th the hoary metalw, for exemple, Meroury.

Aloorting to this, oocalne had coreral

arembers as $100 a l$ enesthotie. It wes too toxio. Al 60 Its eluttens doeempoed rapldiy. beoming woldy with age. mut it bocame avisablo to make new compounds ognthetically or by the al terstion of the cocetine molecule. 
stmplifying the coodine moleotle coenct to be the seneral irund in researoh in alding now lood anowthottos. In 2897 roming(5) doroloped the Bucation, whloh wore made in the following mannom three nolecules of asetone row allowed

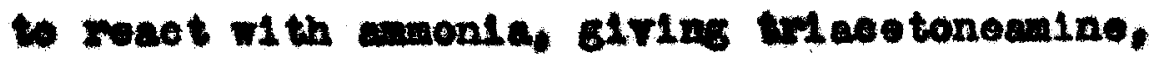
which upen troatment by rartous stops gave

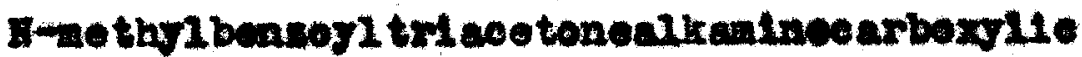
ald nothyl oster or alphe-ououlne. Thil was found to be too toxte and ras won aloplaced by the hraromloride sal ar beaserivinglcetconcalkenlne or bota-oueatno, which was found to be men more active then cocatne as - 100al aneethetic, and only one-tifth as tex10. In 1917 ven Draun(6) diseoverva an ontirely now locel onesthetle whioh was sinpler In strueture then the proeceding ones and was eallod Eocalne, a Aerlvative of ecgonidine. op to now the only onew conskderea hare been the anesthotios with the oomplicated struaturea. we enters of the andine-bensole wolde and the antwo-hydrox benzole aclde are exenples of snother type of local anesthetics. Some are insoluble in water, wo oanot be used uypodernioally, but are used as dusting poinder: fer epen wounds. One of the most important of 
this clase 18 the methy outer of anlnohydrexybensole actd. Belng acld, they are thus Imitent, but form dexiratires that are coluble and noutral to 11 tmul. Tho west inportent dortrative is the braroohlexide sal of Alethrlelye00011 or 11 manine(7).

A great deal of researoh has been done upon the cextratives of androbenzote seld, and many good 100al anesthet10s have been arathoulsed. the riret in exder 1. the ethylertor of pareaminobensole acid, known as Amosthouln, Introaweed by Bing and Kobert(8). Further work on compounds of thl type has show that only where an and group was presont, was the anesthetie cotlen anvorere inliar to that of Anesthouln. The next in order of this sortes is Hovesalne or Rrocaine, 1ntroduced in 2905 by Bunorn and Unlrilder(9). It is the Alethylenino-thyiester of para-aminobensolo ald, a dorrattre of Anapstheatn. This compound, when injected as the bravoblertde salt and with adrenalin, is - rery Importent lecal anesthotio, and 16 gredually roplacting opoatine as woh. It is non1rritant, powerful, and is eno-seventh as toxic as cocalne. Unlike colutions of cooulne, whioh 


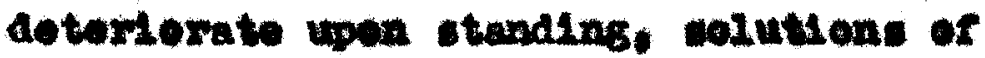

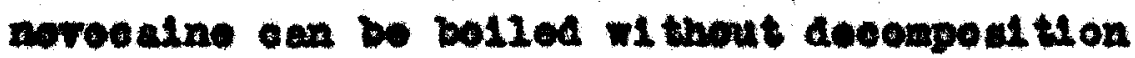
and oan stand for a conviderable length of ume wi thout detemorating.

After the diseovery of noveculne, axteandve werk was done, oppetaly by Heakel and Rogera(10). an erveral lecal anesthetios of the noreculne type, by the acdiriestion of the amino aloobol which forme the ester of bensole cold up the hexy2 aleohol. It wat found that the trang form of tho

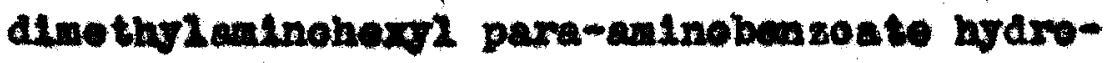
onloride has about tulice the anosthetlo power as the oorrespeading els form. One of this type 16 Butra(11). whioh 1s the albutylaninopropy ester of para-bainobenselo cald. It 18 uged as the hraregeneulfate ealt and is wwoh more toxde then norocalne, so mut be ueed wi th cauthon. Butyn can bo tom11zed by boll1ng. Still another of this trpe 1. Tutoeaino(12). Introduced in 1924

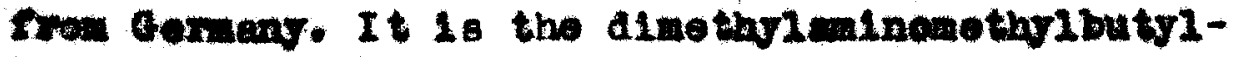
oster of para-undnobentole wold. Tutocalne has ne racecenotrletive ativity and must therefore

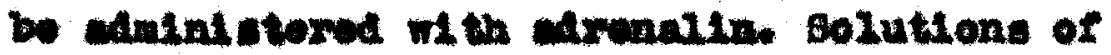

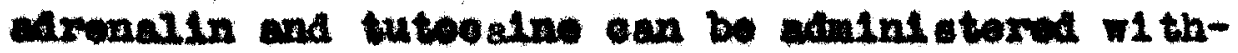
out rear of aowoupout thon, but upon standing 
deterlorate rapialy. A local anesthesia of trenty-four houre duration oan be obtalned by uning the 11quid that containes 0.2 to $0.5 \%$ tutocalne and $0.1 \%$ adrenalin. The 11quid can be therilzed, It not toxio, coos not cause inflanation at the ite or injootion, and the maln point in 1 ts faror 18 that the Ilquid 1teelf 18 an anesthetie.

The latest Inveatigation into thl s type doals with the pyrrole series of local aneathot1os, Introduced by Blioke and Blake in $1930(13)$. Varlous oompound were tried but none came up to the local propertles or cocalne.

The differono between aromatic compound. and the corrosponding aliphatic compounds is largely of degree and not or kind. Upon otudying the ofters of the oarborylic aolds, 1 was found that the diethrianinoethrlester of a carboxy110 ac1d where the carboxy11c erroup wes attached to an unsaturated oarbon atom, thore was 100al anosthotio action(14). Aocording to A. J. Hill there are fourteon different types of compounds that how $1008 \mathrm{l}$ anesthetio action. Sereral of these trpes hare been mentloned already (15). 
As has bea chowa, rariats on of the novecalno

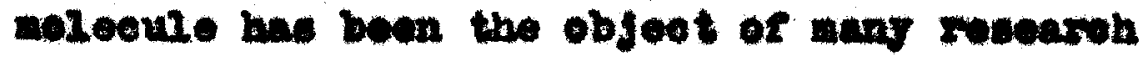
projects. For thcoretioal cenclderation, the noroealne melocule may be divided up into three parte(16):

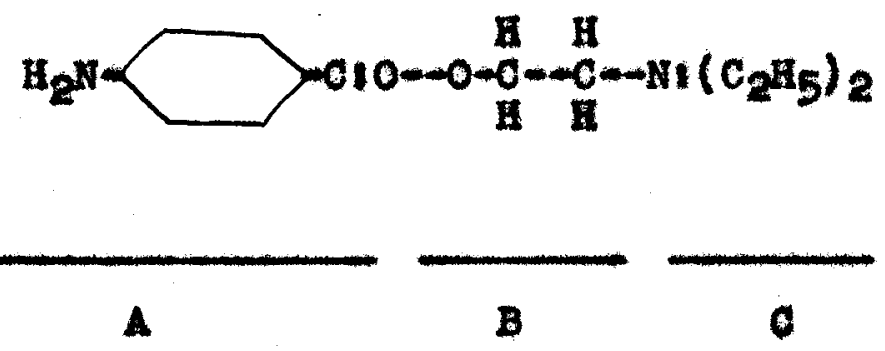

In Butyn, there 1" a change of part $B$ to propg2. and of part 0 to aibutr 2 alno. ntocalne has the variation or part $B$ to nothylbutri, and of part $c$ to dimethriamino. Com has foura(27), upon studring the offeot of the cubatitution of hrarest groups in part $B$, that the increase in the nuaber of hydroxyl groups redued the toxiol tys

The primaxy object of our Investigation whe to vary part $C$ of the noveosine moleowle, using in one case diethanol anine ingtead of diethyl anine, and in the othor, one ethanol realcal 1. ubstuted for an ethyl radioal, at is show in the following formulae 
I.

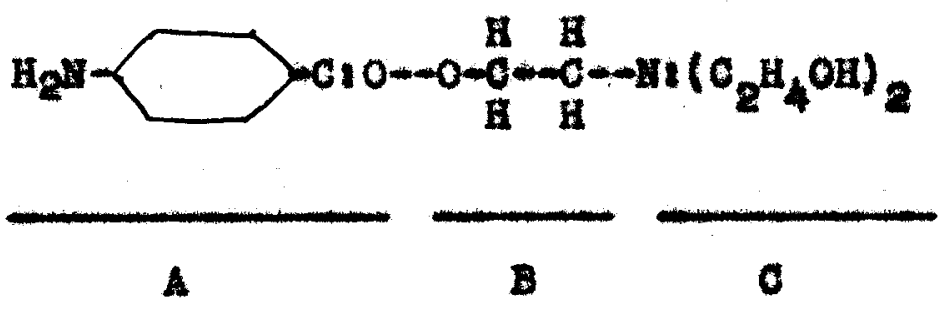

II.

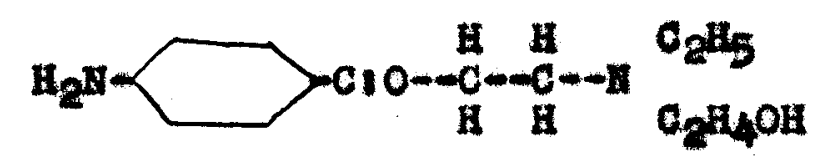

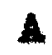

B

c

It wee hoped that these changes would Inorvese velubil1 ty, and lower toxdel ty without too grat a ehange in the phrolological aotion. 
BXXRRTHEN TAT. 


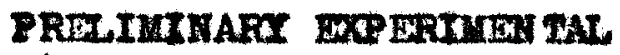


The proulutiary experineatal has been a study of the properties of the othanol enines. because of the Importance of these compounds In the propesed orntheat s.

PREPARA EION OF TRI THANOLAMTNEHYOROCHLORI DB(28)

25 a.c., 0.19 molew, of trlethanol mine was allowed to react $\mathrm{with} 100$ ence of $\mathrm{x} / 10$ bydrochloric acld. A reaction took place imedlately and upon oooling a proclpltate of white crystals wal obtained with a melting point of $166^{\circ} \mathrm{C}$. The product was then rocryotellzed twice from hot aleobel, and the melting polnt rated to $176^{\circ} \mathrm{C}$. The product was soluble in water, bot alcohol, insoluble in other. The yleld was 24 grans, 95 \% of the thooretical, based upon the hydroohlerle weld used.

PRIFARATION OF TRIETHANOLAUTNEHYDROBROMIDE

25 0.0., 0.19 moles, of triethanolemine was allewed to react with 75 c.c. of a $40 \%$ colution of hrarobromic acla. A rosction took place Immodiately and upon coollng whith? proolpl tate was formed wi th a molting polnt of $180^{\circ}$

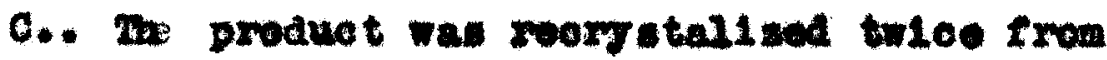


bot aloohol, and the melting point wes ralsed to $186^{\circ} \mathrm{C}$. . The Jieid was 21 grans, 72 of the theerotical, based upon the tripethanolamine usod. The product was coluble in water, hot alcohol, and 1nsoluble in ther.

$$
\begin{aligned}
& \text { PREPARA TION OF DIETHANOLETHMAMINE- } \\
& \text { HYDROBROUIDE(29). }
\end{aligned}
$$

14 8rams, 0.13 moles, of diethanolemins was allowed to roact with 14 grems, 0.128 moles, of ethyl bronide. A resotion toak place 1 mmedletely and upon cooling to roa temperature a white crystaline proelpitate was obtained which melted at $131^{\circ} \mathrm{C}$. Whe product wes reorystalleed from hot alcohol, and tho melting point was ralsed to $137^{\circ} \mathrm{C}$. . The product was soluble in water, hot acohol, and ineoluble in ther. The yield wes 20 grams, $\boldsymbol{n} \%$ of the theoretical, based upon the disthanolemine used.

Thi a wethod of preparation of this salt has not beon used in this rashton according to the 11 terature.

$$
\begin{aligned}
& \text { PREPARATION OF THT SODIUM SALT OF } \\
& \text { DIETHANOLAMINE. }
\end{aligned}
$$

Sodiun was allowed to roaot with 5 grams, 0.047 molee, of alethenolamine until no further 
rwatien took plece. A whi to colld was obtalned wheh was soluble in water and elcohol, but no andydrous wolront wa found that would dissolve the reaction product. Meltins polnt above $360^{\circ} \mathrm{C}$.

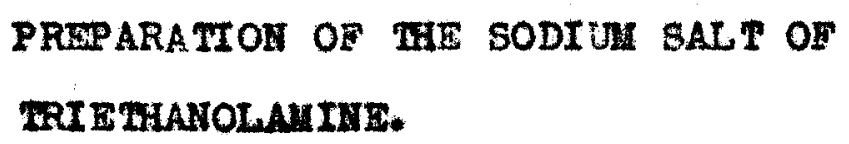

Sodiun was allowed to reeot with 5 grams, 0.034 moles, of trlethenolanine untel no further reation teok plece. A whito tolld was obtained, salublo in rater and alcohol, but as In the proceding experiment no anhrdrous walvent was round, lalting polnt wbere $360^{\circ} \mathrm{C}$. .

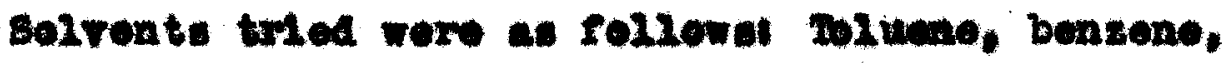
47leae, chloreform, earbontetrachloride, - thyl enedibromide, oarbondl aulfide, $11 \mathrm{groln}$, cacol one, kerosene, other, ethriacetate, abeolute lobbol, ethylemetetrabromide, and pyridine. Pymalno was the only one that in any way hod an action upen the naterial and that only elichtiy when hastod.

SUBSTI TUTIOA OP THE HYDROXN GROUP OP TRIETHANOLAMINE WI TH A BROMTHE GROUP.

2 Eren, 0.004 moles, of triethanolanine byarebroulne was treated with on oxcees of a 
saturated wolution of hydrobromic acid, and was then wealed in a Camul tube. The Carlus furnace was then hoated for $1 x$ and a half hours, the temperature belng kopt around 200$225^{\circ}$ C. . Neter allowing the tube to 0001 orer night, It was opened and the contents oryetial1sed from hot alcohol. The melting polnt of the product was $175^{\circ} \mathrm{C}$. Whe product was then reoryatul1 sed trite from hot aloohol and the melting polnt was ralsed to $185^{\circ} \mathrm{C}$. A mixed melting point was then taken with a semple of pure triethonolamine warobromide and the melting polnt was $183^{\circ} \mathrm{C}$. thereby proving that there bad not been any replacewent of the hydroxyl groupe by bromine atoma.

REAC TION OF ACETIC ANHYDRIDE FI TH ERIETHANOLAMTNE .

10 grans, 0.07 moles, of triethanolenine was mixed with 10 erane, 0.089 molen, of seotic anhydride and varmed on a water bath for 4 hours. The reaction produet was then treated with ary hydrogen chloride and a white procipltate was formed, melting point $165^{\circ} \mathrm{C}$. 
A alxed molting polnt ith ande of pure trlethanoleminajaroenleride gave a molting polnt of $169^{\circ} \mathrm{C.}$, wowlus that thore had not been a reaction betweon the alcohollo groups of the triethanolanine moleoule and the acetic ankydrde. 
FINAL EXPIRTHEN TAL 
PREPARATION OF THE BETA-CHLOROETHYEE TER OF PARA-AI TROBENZOIC ACID.

90 grams, 0.49 noles, of para-ni trobansoyl onlortde and 50 grams, 0.6 molos, of ethylene oblorohyartn (125 c.0. of the $40 \%$ solution) were hested in a round botton Mask comeated to - renux condenser on an 011 bath at a teaperature

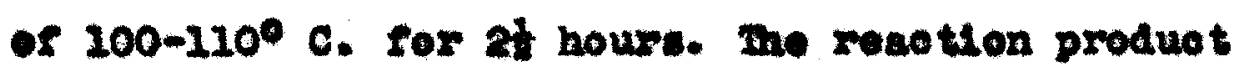
was cooled, riltered, washed with water and iried on a porous plate. The melting polnt of this pro-

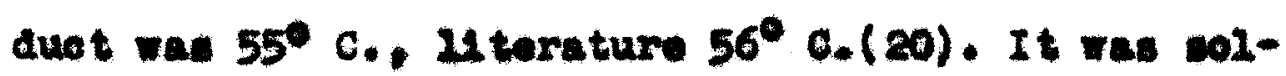
uble in hot alcohol, and Incoluble in wator and ether.

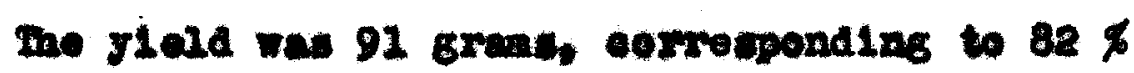
of the theoretieal. mere was obtained 10 grams or para-nitrobensolo sc1d, 11 \& of the thooretion, whlch was probably formed by hydrolyale. The wraregen obloride gas that was given off during the reaction we neutrallzed by absorbling in a eolution of dilute mentim hydroxdae.

It was found in the rirat rum that the jleld of para-nitrobentole cold was antl roly too ntgh. There were only two factor: to take into condaeration in the proosedure. rirut the temporaturn, and the second was the Hine. Sereral 
mua wore wade uslng oxiy 10 grant, 0.054 moles, of para-nltrobensoyz obleride and 4.34 grams, 0.058 moles, of ethylene oblorohrams ( 11 0.0. or the $40 \%$ celution). Hine was the only ractor ramed. It wes found that the highoet ylold. $89 x$ of the theoratioal, of the centred produst wa obtained in the run that was heated for only tronts minuten, and the gleld of parmal trobensole weld was reduced to 0.44 crems. or 5 of the theoretion.

REDUC TION OF THE BE RA-GHLORORTHYIESTER OF PARA-NI TROBEAZOIC AOID.

10 exan, 0.043 moles, of the ester was dissolved in alcohol and redued wh th th and Q11ute bydreablorle acld. The tempercture was not allewed to riwe abore $40^{\circ} \mathrm{C}$. and was kept fer the nost part betwien $35-40^{\circ} \mathrm{C}$. After the reaction wail complete. the raak ras allowed to 0001 to room temperature, and white exytaline preelpl tate res romed. This coupand wes roorytialled from alcohol and the welting polnt was foumd to be $165^{\circ} \mathrm{C}$. . Ascoxding to the Ilterature, upan ruduetion of the beta-ehloroothrlenter of para-nitrobenzole actd the product ery tallees out having a melting polnt of $87^{\circ} \mathrm{C}$. 


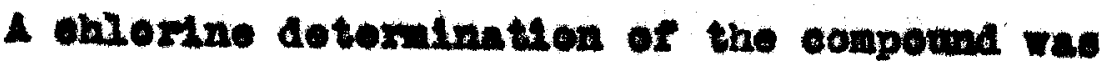
Non of the Folnurd nethod and the perventage of rroe ondertive wat found to be $10.66 x_{*}$

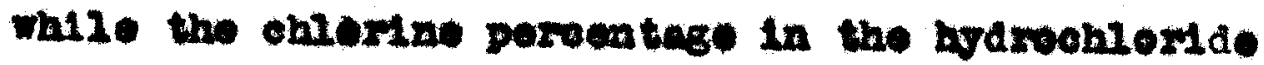
al of the bota-onionethylester of para-

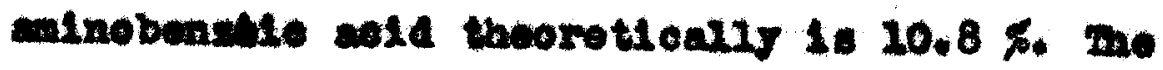
Jield was oniy 5 grame of the reast or procust. is $x$ of the theorotioal, baped upen the unownt

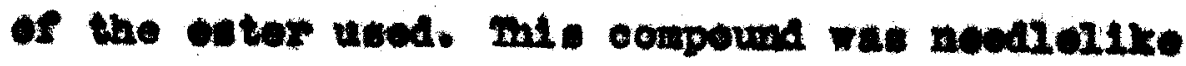
In otrueture and whit in coler. It was coluble in vater and alcohol, and ineoluble in other.

In a cooond 10 grame, 0.043 moles, of the ester was alsealved in aleobol and roduced Wt th samous abloride and alute hrdroablorio sota. The temperature contrel was the wane al in the rirot mu. Arter the reaction was complote, the Rakk was allewed to 0001 to soow temperature and a wite exyetaline colla proolpl tated. hats oompound rat reerystallect from aloohol and the melting polnt was found to be $164{ }^{\circ} \mathrm{C}$. sane af is the firot run. A mixed welting point was then ria on the two amples and the wolting polnt did not enange. The ylald was 3.6 grent of the reaction product, or $35.3 \mathrm{x}$ of the thoeretioal. 
In a thind ma 20 grans, 0.043 males, of the ester wee difrelrod in aloohol and roduced with Iron and allute hydrochlorte scld, inder the weme condt tlors as in the first two rmo, and upon coolling to room temperature a whlto precipl tate wae formed. Thi product could not be purified by recry tallsatlon frow alcohol bockuse of the Iren chloride provent in the cuple. The compound was washed w1 th othor w1x thes and the mel ting polnt was found to be $162^{\circ}$ C.. A nixed althes polnt with a semple fron min ono wat taxen, and was found to be $159^{\circ}$ O., showling these twe to be Ldentleal. Al though the best yleld was obtalned 1n this run, 6.7 greme or $65.6 \%$ of the theoretteal. the axcoes inon obloride cowld not be eliminated, and therefore thl wethed of reduction could not be used in the progaration of the anine deatrod.

In a rourth min $10 \mathrm{grams}, 0.043$ moles, of the ester wae diseolred in a mixture of aloohol and weetone wa redued under the seme condithons ane in the rirst run. Upon coolling to rove temperature, no proelpitate was formod. The volution was then treated with hydrogen sulfide to preolp1 tate out the excese stemous and stannic enloridow, flitored and the fltrate craporated to about one half 1 te rolume and allowed to ceol. 
A white erystaline solld was obtained that mel ted at $164^{\circ} \mathrm{C}$. The yleld was 3.1 grams, $32 \%$ of the theoretical, of the reduced enter. 5.2 grams of para-aminobonzole acta hydrochloride, or $68.5 \not$ of the theoretical, was al oo obtalned.

In a f1fth mun $10 \mathrm{grams,} 0.043$ moles, of the ester was dissolved in a mixture of alcohol and acetene and reduced as in min two under Identloal conditions. The stannous and stannic oblerides were preclpitated out $\mathrm{w}$ th hrdregen gulfide, and the excese acld was neutrallzed with a saturated solution of sodiun carbonate. The solution was then eraporsted to about half Its volume. When coolea, a wht te exystallne procipl tate formed, melting point $164^{\circ} \mathrm{C}$. . The J1eld was 3.6 grams, corresponding to 37.2 of the theoretioal. mere was also obtalned 4.8 gram of para-aminobenzole cold byarochlorlde, corregponding to 63.3 of the theoretical, based upon the acid formed.

In a sixth $\operatorname{mun} 10$ grasis, 0.043 moles, of the oster was a1ssolved in acetone and reduced as in the preceeding experiment under the same conditions. When the reaction product was cooled no preclpitate appeared, wo the colution was 
waporated to about half ita rolume on a water bath and then cooled. Only 1.3 grams of the reduced ester was formed or $12 \%$ of the theorotloal. On furthur waporation of the filtrato, 6.4 erams. 85 \% of the theoretioal, of para-andnobensole acld hydrochloride was formed.

It was orident from these experiments that the best agents to use for reductlon were tin and allute hydrochloric acid in alcoholle solution.

REAC TION OF DIETHANOLAMTRE AND THE BETACHLOROE THYLES TER OF PARA-NI TROBEMZOIC ACID.

In this run $10 \mathrm{grams,} 0.098$ moles, of diethanolabine and 20 grans, 0.087 moles, of beta-chloroethylester of para-ni trobenzole acla were placed in a hadk connected to a reflux condenser and warned on a water bath for 45 sinutes. The product ras allowed to 0001 to room temperature, and was then extracted with chloreform. Yollow nedilellke oryetals wore obsalned on craporation of tho chloroform extract, moltins at $115^{\circ} \mathrm{C}$. . When recryetallzed from cheroforn, the melting point was $130^{\circ} \mathrm{C}$.. This material was soluble in water and alcohol, yleld was 12 grans.

Thls reaction product was then snalized for free chlorine by the Volhard method(22), and 
only $1.059 \%$ free oblorlne was found the theoretleal porecatage of froe oblomine in

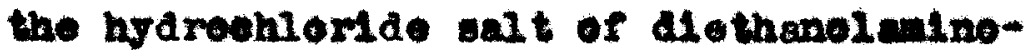
ethylostor of para-ni trobensolo aold $1.10 .6 \%$

A water solution of this product was tested on the tip of the tongue for anesthetic propertios and allght numbaese eocurod.

REACTION OF BETA-CHLOROETHLESTER OF PARAAMINOBENZOIC ACID HYDROCHLORIDE AND DIETHANOLAMINE.

In the flret $\tan 5$ grang, 0.0212 moles, of beta-obloreethylester of para-aninobensole acld hyareohlorlde and 3 grame, 0.028 moles, of diethanoliane were placed in a Madk conicotod to a roriux condencer and hoated on a water bath for throe hourd, On cooling to roo tenperature there were two oubstanoes in the reaction chamber, a I1quid and a wolld. The 11quid was extreoted with obloroform, and when the ohloroform oxtract was oraporated, a white oryetalino solld was obtained, nelting at $272^{\circ}$ C." since thit melting polnt was so near the melting polnt of triethanolemine prarochioride, a mixed melting polnt was taken with a semple of pure triethanolanine hydrochloride. There 
wax a change of 1 degree in the mel tung point, chowing the two to be laention. The jield was 2.8 grane or 74.3 \% of the theoretien. The formation of the triethanolumine hydrochloride Indleated that there hod been an addition of the diethanolemine to the oblerine aton on the ond of the ethyl ohaln, and a subsequent epll thing of the eater.

Al though hadrolyal of the ostor had taken place In the reaction deseribed ebore; analy ula of the solld was next taken into conalderation. The reaction product wae found to be only uightly wible in water and cola aleohol, woluble in mineral aclds, and inooluble in othor and obloroform. Upon Alssolving this product In hot aloohol, docompost tion toox place giving - pale jellon oryotaline colld. Upon analyal of this product it was found to be para-antino beasele acld. Finl indicated that this produst was cone conplex cempoumd of para-aninobenzole sold. The aulting point was not wharp, cortening at $90^{\circ} \mathrm{C}$. " and rinally melting at $102^{\circ} \mathrm{C}$. 
Analyals for free oblorine by the Velhard method gave 10.88 \% froe chlortue, the theoretical per oent of free chlorine in the hrdrooblorde salt of diethanolaninoethrioster of para-aninobenzolo ac1d hydrochloride was caloulated to be $10,41 \%$ for one aton of oblorine or $20.82 x$ for two atom of oblorine. The yleld was 0.5 grams.

In a bocond rua. 5 grame or 0.0212 moles of the outer and 3 grume, 0.098 noles, of diethanol alne wore dieselred in alooblel and were rofluxed for 2 hours on a water bath. As before, there wore two products formed. the 11quid was extracted with olloroform as berom, and was fomd to be trothanolenine hydrechloride. The yield was 2.2 gxine or $56.5 \%$ of the theeret1cal, or a deorease or 17.8 fren that obtained in the riret rm. wo free onlorine in the solla preduet was titrated by the Volnard wothod and caloulated to be $10.95 \%$ or eary - rarlatson of $0.07 \%$ rrom that obtained In the firut ma. Beforo testing for oblorine the oompound was wadned with wates and cold alcohol to be sure that all of the triethanol anine hydrechloride was ellminated. The jleld mas 1.6 grang. 


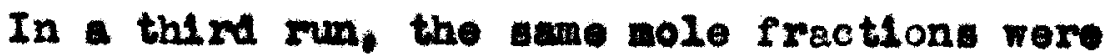
used as in the flret two mme. The mixture was placed in a Mlask connected to a rerlux condeneer and was then disolved in alcohol. Due to the fact that there had boen hydrolyel takdne place In beth of the former runs, it was the object of this rin to determine whethor temperature had angthing to do with this. The resetion was kept at a temperature not greater than $40^{\circ} \mathrm{C}$. and for the mot part it was rept betroen $38-40^{\circ} \mathrm{C}$. . Thl reation was allowed to run for two houre at this temperature, arter which 1t was allowed to 0001 to reom temporature. As In the precoeding rme there were twe reaction producte. Upon analy als of these products, they were found to be ldentical to those that had occured in the two prevtous runis. The rield of triethanolanine hydrochloride was 2.9 grans or 50.3 of the theoretieal. $\mathrm{mi}$ was. a deerence of $6.5 \%$, when compared to the second rm, apparently caused by a rarlation In temperature of $38.4^{\circ} \mathrm{C}$. . The riela of the wolld matorial was 1.8 grams.

It was found that in the three rume tried that there had boen hydrolysis in every case, Noo the higher the temperature, the higher the peroent of hydrely ol taking place. 
In a fourth me the seme mole pereentages of the ester and diethanolenine were used as In the throe provtous runs. Thl expextucht was conducted as In the provious mis with the exepption that after completion of the hoating of the material, the product was placed in an oraporating dith with a matoh glase cover and allowed to stand for a rook. This was done.' for the purpose of determintas whother or not the triethanolamine hydroohlerde rould eryutalize out upon standing. It was found that on the thist Car a rom axyetals appeared and at the end of the weak the 11quid portion of the rosetton product hod boome colld. mowe erystais woro alssolved in hot aloohol and reorystallzod. The jleld was 2.5 Brams or $66.7 \%$ yleld of the theoretical.

PREPARATION OF BETA-CHLORORTHYLSTER OF PARA-AMINOBENZOIC ACID.

Due to the faot that otrons alkall appeared to break the oster formation, it was nocessary to try raxlous concentrattons to wee what one was the best for the oplitting out of the hrarogen onloride noleewle from the anine molecule. 
It was round that tho oster 1 inkege was broken whonover solution of groater strongth than 10 \% godive hrdroxide was used. Al so that the IInkege was broken whoncvor a high coneentration of codlum earbenate was used. A fire porcent nolution of coditum carbenate wa found to give the hlghest j1eld.

5 srma, 0.0212 moles, of beta-ohloroethyl -ater of para-aninobensole acld brdrochloride was troated with a 5 , celutlon of codiun carbonate In a ulght excese. A whi te proelpitate wal formed at thie polnt, and the reaotion produst was 111 tered, wathed with water and the prealpl tate dred on a porous plate. The melting polnt was $84-85^{\circ} \mathrm{C}$, 11 terature $86-87^{\circ} \mathrm{C} .(21)$. The yleld was 1.3 grama or 34 \% of the theoretical.

REAC UION OF RETA-CHLOROETHYLES TER OF PARAAMINOBENZOIC ACID AND DIETHANOL AMINE.

5 grams, 0.025 moles, of the enter mae placed in a rlask with 2.5 grams, 0.023 moles, of alethanol amine and hoated on a water bath for 2 hourw. The raaction was then allowed to 0001 to wom temporature, ether extrectod and the othor catraet ovaporated, whioh care no rosidue. The veluttion was then raoumn distilled, 
at a temperature of $67^{\circ} \mathrm{C} .$, and a pressure of $10 \mathrm{~mm}$. The product decompesed at this stage and a large porecatage of Alothanol anlac was obtalncd. A mall canple of para-anlnobeasole cold was obtatned, but not in currielent quents tios - ther then to obtain a melting polnt and a mixed melting polnt with pure sample in order to prove that it was the product mued. Trlothanel une hydreohloride was romed in this experinent,

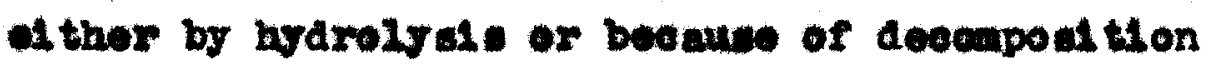
by temperature. This was not detormined. mo Jield of diethanol unthe was 1.3 grang, and of triethanoluaine bydroohler14e, 1.1 greme.

In a weond rum, the same nole percentages were used as in the flrst run. The mixture of matorial was ploced in a proseure rlack and heated at tomperature between 110-120 $\mathrm{C}$. for 3 hours. The rlask was thon allowed to 0001 to reon temperature and the producte analyzed. The product was extraeted with weohel and the alcoholle colution oraporated. It was found upen analyala of the realdue from this oraporation that the produet wan trie thanelemine pydroohloride. mis was proven by a mixed meltung polnt with a seaple of pure triethanolanine hydrochioride, whioh 
nel ted at $174^{\circ} \mathrm{C}$. . The yleld was 1.4 grame or 32 of the theoretical.

In a thind rum, the mane nole percentages were used as in the prodecalng rums and the mixture was diswoived in aloohol. The Rlaks was then attached to a reflue condencer and warmed on water bath for 2 hours. Arter allowing the Ilakk to 0002 to room terperature, $10 \mathrm{c.0}$. of 20 selution of sodiun prdroxide was edded and then other extracted. No produot appeared upon waporation of the ether extraet, so the rosidue from the ether extraction was then Tacknn aluth iod at the sane conditions as in the firet run. The reaction products were the seme as those in $\mathrm{mu}$ oxe. The yleld of diethanol anine was 1.4 greme, and of triethanolesine byaroohloride, 1.04 grams.

It was ovident from this sories of runs on this reaction that there had been a slight addition of the diethenolamine molecule to that of the beta-chlore atom of the ester but that hydroly is had taken place in ovory mun. Approximate jlolde were obtained in orery case. 
PREP KRA TION OF ETHYLAMINOE HAMOL

20 30 o.c. of the $33 \%$ solution of ethy ane having apeolfle gravity of $1.225 / 4$. 0.46 moles. 40 c.0. of the $40 \%$ solution of -thylenochlorohydmin was added and warmed on a water bath at $60^{\circ} \mathrm{C}$. for 1 hour. The hydroohloride walt of ethylaninoethanol was then troated with a 20 \& melution of wodiun hydroxido unt11 the wolution vas netrellsed, a total of 52 c.c. of sodlum hjdroxide belas used in all. The solution was then alstilied up to $110^{\circ} \mathrm{C}$. where the codiun ohlorde erystallzod out, and wai then oooled and filtered. The filtrate wa placed in a Clal gon Nlakk and rractionstod. All distillate up to $165^{\circ} \mathrm{C}$. was thrown away, keeping all botwoen $165-170^{\circ} \mathrm{C}$.(19) This traction was then distilled in the same apparatus as bofore, keoping only the Iraction that cane off at $167-269^{\circ} \mathrm{C}$. The j1eld was 26.2 gram or $78.1 \mathrm{~d}$ of the theoretical. The properties of this product corresponded to thowe given in the 11 terature(19). me product was soluble in water and alcohol, and was incoluble in ether. 
REAC IION OF ETHYLAMINOETHAYOL AND BETACHLORA ETILESTER OF PARA-AMINOBENZOIC ACID.

5 eram, 0.025 moles, of the oster was placed In a rlask and 2.2 gram, 0.026 moles, of ethylaminoethanol added. The llack was heated on a water bath for 2 hours. There were two aubstances in the reaction ohember upon oooling whioh upon analy 1 d wore found to be the same as what had been added, thus proving that there had hot been a reaction at this temperature.

In second run the same mole percentages wore used as on the flrgt rm. The mixture was desolved in alcohol and heated on water bath at the bolling polnt of alconel for 2 hours. After belng allowed to 0001 somewhat the volution ras placed in an ovaporating dith and the aloohol ariven of by ovaporation. The remalning solution was thon vecum distilled at a temperature of $65^{\circ} \mathrm{C}$. and $8 \mathrm{~mm}$. pressure. The product decompesed at thl temperature and only a mall wangle of liquid was obtalned whioh upon analys was proved to be ethyleminoethanol, bolling polnt $168^{\circ}$ C. at $757 \mathrm{~mm}$.. 
Conchustoms 
CONCLUSTONS

It 1s orldent from those experiment: that in the proparation of alethanolaninoothrlester of para-aninobenzole acid by the action of diethanolanine on the botachloreethyleater of para-aninobensolo acld, bydrolyat tokes place before a tinal product can bo I velated. However in the roaction of Alethanolanine on the beta-chloreethylester of para-nitrobensole aeld there is a reaction fran which a final preduct can be 1 solated. mis substance produces a wlght numbness on the up of the tongue when a dilute aloution of thl product 1s applied. Howerer 1t does not contaln the amount of free ohlorine Indieated for the hydrochloride salt of diethanoleminoethylester of para-ni trobensole seld. 
BIELIOGRAPHY 


\section{BIDLTEOR YHY}

2. Loake, Solent1810 monthly, 20,304-312,(18:1).

2. Merok, B6r, 28, 2264, (1386).

3. Lokson, A., 133, 35:, (1.34)

4. Limoat Foumeau, viondo Madicents and the1r

Preparstion, Blakiston's gon and Co., PhIladolphia,

page $68,(2225)$.

5. Morling, D.R.P. 90, 245, O., I, 1231, (1886)

6. Braun and kullar, Ber., 51, 238, (1918).

P. Einhorn, L.R.P. 103.027, C., 883, (2800).

8. B1ng and Kobert, D.R.F. 147,580, Ber., 28, 1821,(1898)

9. Einhorn, D.R.P. 172,568, 0.7 I, 473, (1906).

10. Heckel and Rogere, J. Are, Chom, S00.,

$48,1303,(2227)$.

11. Neaker, J. Tharm, and ixp, Theap., 2x, 376,

(1826), C.. I, 2818, (1926).

12. Solfert and Anthon, Dout. Hed. Hochsohr.,

$50,326-30,(1924), C . A ., 28,2 x, 3,(1924)$.

13. Blloke and Blake, J. An, Chem, soc., 6R, 235, (2030).

14. Adans, J. Am. Chenn. S00., 50, 437, (1028).

12. A. J. H121, Present qrendo in the Synthesie

of Locel Anestho t10e, Indlanapol1s, Ind., (1931).

16. Blloke and Blake, J. Am, chen. Soo..,

63, 1016, (2052).

17. Cow, J. Am, Ohem. S00, 47, 2660, (2825). 
BIELIOGRAPHY CON TINUED.

18. Knox, Bex., 30, 918, (1897).

19. Snorr and Somidt, Bor., 31, 1074, (1898).

20. Luelu: and Bruning, D.R.P. 179,627,

c. 2365, (1907).

21. Uhlfilder and Ethhorn, D.R.P, 194,748,

c. $1005,(1908)$.

22. Edwark Mabin, Quanti tative Analy ols, 250, (2924). NoO rew-B121 BOOK O., InC., Now York, H.Y. 
- AB MOETOCRAPLX 


\section{AU TOBIOGRAPHY}

The author, w21bur 2. Crouch was bexk at Tonnessee, I111nols, July 16, 1907. He rooelved his high wohoel edwation at Galesburg Algh Sobool, Galesburg, I111nols. He reoelved hl udergraduate edveation at Lembard College, Galobburg, Illinols, froe which he graduated, with a major in Chealetry and alnor In Mathematice, it th the degree or Bacholior of selones, in 2929. He rooetred an appointaent to an AgBl stantehlp in Chemistry at the Unireral ty of Loul or211e in 1929 and held this position for two yearw. During that time he did graduate work at the Undrerelty and redelved the degree of Master of selence In June 1931. 